\title{
Attitude of Secondary Students towards the Use of GeoGebra in Learning Loci in Two Dimensions
}

\author{
Sheela A/P Rajagopal ${ }^{1}$, Zaleha Ismail ${ }^{2}$, Marlina $_{\mathrm{Ali}^{2}}$ \& Norhafizah Sulaiman ${ }^{2}$ \\ ${ }^{1}$ Ministry of Education Malaysia, Malaysia \\ ${ }^{2}$ Faculty of Education, Universiti Teknologi Malaysia, Malaysia \\ Correspondence: Norhafizah Sulaiman Department of Educational Sciences, Mathematics and Creative \\ Multimedia, Universiti Teknologi Malaysia, Johor Bahru, Malaysia. Tel: 60-13-373-6632. E-mail: \\ norhafizah52@live.utm.my
}

Received: November 3, 2014 Accepted: March 13, 2015 Online Published: June 25, 2015

doi:10.5539/ies.v8n13p27 URL: http://dx.doi.org/10.5539/ies.v8n13p27

\begin{abstract}
The use of computer software has good chance to form an efficient and powerful learning among the students. On the other hand, using open source software to teach mathematics in the school system of Malaysia, particularly in secondary school is still an uncertain issue. As a result, in an attempt to bring in a freeware, GeoGebra, this paper studies the attitude of form two students towards the utilization of GeoGebra in learning Loci in Two Dimensions. This study was conducted with 30 form two students from a secondary school in Johor Bharu district. In the beginning, GeoGebra was used to teach Loci in Two Dimensions and then followed by a survey. Questionnaires were provided to investigate the attitude of the students towards GeoGebra. A research model which was modified from the Technology Acceptance Model (TAM) was used to develop the questionnaires in order to study the students' attitude. Later on, the data were analyzed by using Statistical Packages for Social Sciences 19.0 (SPSS) software to find the correlation coefficient and regression results. The result revealed that the students showed positive attitudes towards the use of GeoGebra in learning Loci in Two Dimensions. At the same time, there was a significant relationship between perceived ease of use, perceived usefulness and attitude of students towards GeoGebra. This positive attitude of students will bring to positive behavioral intention to use GeoGebra in the future. At last, the implication of the research and recommendations for the future research also are discussed in this paper.
\end{abstract}

Keywords: attitude, GeoGebra, loci in two dimensions, secondary students, technology acceptance model

\section{Introduction}

In the world of today, technology is in everything and everywhere around us. Most of the fields are enjoying the benefits of technology with a broad smile. The list of the fields mentioned is such as medicine, construction, transportation and so on. However, does the technology possess a place in the classroom? The answer is yes. The use of technology in education enhances the students learning and helps the educators to encourage a constructivist class environment (Muir-Herzig, 2004).

Mathematics is a mental activity which is essentially subject for every individual in this universe. The knowledge of Mathematics is a fundamental for problem solving, logical thinking and reasoning for daily basis. To excel well in Mathematics, high level cognitive processes such as critical thinking, reasoning and imagination are required. In this respect, using pencil, paper and board are not sufficient to cultivate those processes. Many computer applications have been developed explicitly to engage learners in critical thinking (David, Chad, \& Hsiu-Peng, 1998). Therefore, Mathematics should be approached with different types of learning methods where students can enhance their understanding and make the learning fun (Dogan \& Icel, 2010).

In general, several instructional approaches are available to convey Mathematics knowledge to the students such as lecture method, inductive-deductive method, computer-based learning, demonstrative methods and so on (Antohe, 2011). Furthermore, according to Chan and Zaleha (2014) mathematics involves deductive reasoning where a conclusion is made rationally based on definitions and axioms while statistics involves inductive reasoning where the conclusion may be vague but is still acceptable and legitimate. The teachers, who are the main gates of allowing any kind of a new integration of technology in the education system, can use the 
technology to transfer mathematical problems into actual and real environments. This will enable the students to carry out real tasks and explore the problems deeply. Computer software for teaching mathematics is springing up in the market. The existing software which helps to master mathematics among others, are Mathematica, Matlab, Maple V, Geometers' Skethpad, and Autograf (Kamariah et al., 2009). Besides that, Chan and Zaleha (2012) said there are tools can promote pedagogical innovation and curriculum reform rather than retaining its traditional function, which is to support the statistical reasoning of students.

Although there are ample supply of software such as mentioned earlier, but those softwares need the users to purchase licenses in order to make it legally install in the school computers. The one and only solution for this is by getting the open source software such as GeoGebra. GeoGebra as a technological tool has several features to support mathematics teaching apart from being a freeware, with proper structured activities; the use of GeoGebra has potential to encourage discovery and visualization in the mathematics classrooms (Hohenwarter, Hohenwarter, Kreis, \& Lavicza, 2008). As for GeoGebra, it is indeed suitable for the objective of teaching and learning of topic Loci in Two Dimensions because the teachers can show the geometric constructions and the corresponding algebraic functions simultaneously (Stojanovska, 2010).

Even though the integration of technology in mathematics learning has become very trendy, but the effectiveness of technology in mathematics still remains a debatable issue in the board of education. In order to find a solution for the problem, the concrete reason behind this issue must be addressed first. It has been proved by many researchers that the students' attitude is the backbone for the success of any instructional approaches or integration of technology in the educational system (Alexiou-Ray, Wilson, Wright, \& Peirano, 2003). According to Volk and Yip (1999), in order to lead and forecast the upcoming actions, students' attitudes are playing a major function. In fact, the participation level of students in the society is affected by the negative or positive attitudes of students towards the technology.

Therefore, this paper makes a deep research on the students' attitudes towards the integration of GeoGebra technology in the learning of Loci in Two Dimensions. In Malaysia's education curriculum, this topic is being taught in form two. Locus is described as the set of points or lines which satisfy the exact conditions (G. Gorghiu, Pauna, \& L. Gorghiu, 2009). This topic consists of four loci which are circle, perpendicular bisector, parallel line and angle bisector (Ministry of Education, 2002). Even though there are only four loci, but the students find complexity in understanding the concepts of loci in two dimensions and to relate them to their real life (Alexiou-Ray, Wilson, Wright, \& Peirano, 2003). The students found difficulty in understanding the concepts of loci and demonstrating a geometrical locus (Gorghiu et al., 2009). As a result, this circumstance will lower their motivation level and their performance in the academic level as well. To date, many researchers have conducted researches on GeoGebra on attitudes towards the technology in education in many topics such as Geometry (Botana \& Abánades, (2014), Intergers (Reisa, 2010), Trigonometry (Zengin, Furkan, \& Kutluca, 2012), Calculus (Volk \& Yip, 1999), Algebra (Hohenwarter \& Fuchs, 2004; Hohenwarter \& Jones, 2007). But researches on specific topics like Loci in Two Dimensions still as countable as the fingers on one hand. In this case, the positive or negative attitude of students will determine the effectiveness of GeoGebra on learning the Loci in Two Dimensions. The primary factors that are influencing the students' attitudes towards the use of GeoGebra in learning the particular topic can be identified by using the modified model from Technology Acceptance Model which was introduced by Davis in year 1989.

\section{Method}

This research is non-experimental research which uses correlational research. This research design to determine the attitude of form two students towards the use of GeoGebra in learning Loci in Two Dimensions. This research investigates the relationship between perceived ease of use, perceived usefulness, attitude of students and lastly behavioral intention to use GeoGebra in learning this topic. After identifying the research problem, data collection method and the sample were determined. In this research, questionnaires were designed to collect data. Subsequently, instruction with GeoGebra was conducted in this follows by survey. The data from the questionnaires were collected and analyzed by Statistical Packages for Social Sciences 19.0 (SPSS).

Homogenous sampling was chosen with the aim of choosing a sample which shares the same characteristics especially form two students in this research. The population of this research is the form two students of a secondary school in Johor Bahru district. All of these form two students have studied Loci in Two Dimensions through the conventional method. In this research, the sample size consisted of 30 form two students from a secondary school in Johor Bahru district. The researcher conducted the lesson by using GeoGebra. There were six lessons which were conducted in two days, five hours per day. The students were given notes and worksheets too. After each lesson, the researcher asked the students to do the activities in the GeoGebra applet and the 
worksheets given. The lesson was conducted in two directions which is a healthy and conducive learning style. The students are encouraged to ask questions if they had any doubts in the lesson. The researcher has been a facilitator during the lesson. Here, student-centered learning was promoted highly which will produce creative students. After that, students were given a set of questionnaires consisting 18 closed ended questions and one open ended question divided into three sections. Sections A is about the background of the students. 12 questions were set including students demographic variable such as gender, race, grade in mathematics, prior use of GeoGebra, computer and internet. Whereas section B consists five segments where four segments are closed ended questions with Likert-type statements. The questions in section B are based on the 4 constructs in the conceptual framework which was adapted from Technology Acceptance Model (TAM). Section C is an open ended question which asked the students to write down the experiences in learning Loci in Two Dimensions with the support of GeoGebra.

The data from the questionnaires were collected and analyzed by Statistical Packages for Social Sciences 19.0 (SPSS). The hypotheses were tested for its significance by using correlation and regression test. There are total of 18 items which were used to analyze the attitude of students in learning Loci in Two Dimensions by using GeoGebra. Construct behavioral intention has alpha values above 0.70 which means this construct have acceptable measurement items. While construct perceived of use, perceived usefulness and attitude have very good measurement items since the alpha values show above 0.80 . The overall Cronbarch's alpha for all the items is 0.942 . This results points towards that the research instrument is a reliable tool. In addition, past studies had used all of the measures of constructs and therefore they are indeed validated.

Table 1. Analysis of measurement reliability

\begin{tabular}{lccc}
\hline Construct & Number of Item & Cronbach's Alpha & Overall Cronbach's Alpha \\
\hline Perceived ease of use & 6 & .820 & .942 \\
Perceived usefulness & 6 & .829 & \\
Attitude of students & 3 & .817 & \\
Behavioral intention & 3 & .782 & \\
Total & 18 & & \\
\hline
\end{tabular}

\section{Results}

This result provides the outcomes which were obtained from the research conducted in a secondary school in Johor Bahru district. The demographic profile demonstrates that $66.67 \%$ of Malay students, $30 \%$ of Chinese students and $3.33 \%$ of Indian students responded the questionnaires. Moreover, $40 \%$ males and $60 \%$ females became the respondents of the questionnaires. As for the mathematics grade in the mid year exam, $30 \%$ of students obtained A, $50 \%$ of students obtained B, $13.33 \%$ of students obtained C and lastly $6.67 \%$ of students obtained D. Nobody scored E in the mathematics exam in mid year exam. Exactly none of the participants reported aware of the existence of open source software earlier

Table 2. Summary of results

\begin{tabular}{llccc}
\hline Null Hypothesis & $\begin{array}{c}\text { Significant } \\
\text { at the } 0.05 \\
\text { level }(2 \\
\text { tailed)-p }\end{array}$ & $\begin{array}{c}\text { Pearson } \\
\text { Correlation } \\
(\beta)\end{array}$ & $\begin{array}{c}\text { Significant } \\
\text { relationship }\end{array}$ \\
\hline H1 & $\begin{array}{l}\text { Perceived ease of use has no } \\
\text { relationship with perceived } \\
\text { usefulness of GeoGebra }\end{array}$ & 0.000 & 0.803 & Yes \\
H2 & $\begin{array}{l}\text { Perceived ease of use of } \\
\text { GeoGebra has no relationship } \\
\text { with attitude towards GeoGebra }\end{array}$ & 0.036 & 0.762 & Yes \\
\hline
\end{tabular}




\begin{tabular}{llll}
\hline \multicolumn{5}{l}{ Perceived usefulness has no } & & & \\
relationship with attitude & & & Yes \\
towards the use of GeoGebra in & 0.039 & 0.761 & \\
learning Loci in Two & & & \\
Dimensions & $\begin{array}{l}\text { Attitude has no relationship with } \\
\text { behavioral intention to use } \\
\text { GeoGebra in learning Loci in } \\
\text { Two Dimensions }\end{array}$ & & \\
Hes
\end{tabular}

From the results in Table 2, it was revealed that perceived ease of the use had a significant relationship on perceived usefulness since the $\operatorname{sig}(\mathrm{p})$ is less than 0.05. Similar to earlier studies (Dogan \& Icel, 2010; Alexiou-Ray, Wilson, Wright, \& Peirano, 2003). This research also proved that if the students find the software is easy to use, then they will find that the software is useful for them. Since perceived ease of use and perceived usefulness is significant and quite strongly correlated $(\beta=0.803)$ then the hypothesis 1 is accepted.

Perceived ease of use and perceived usefulness of GeoGebra have a significant impact on students' attitude towards GeoGebra since the $\operatorname{sig}(\mathrm{p})$ value is also less than 0.05. According to Technology Acceptance Model (TAM), attitude is influenced by variables perceived ease of use and perceived usefulness. Based on the result, perceived of use $(\beta=0.425)$ has a significant and positive impact relationship with the students' attitude towards GeoGebra in learning Loci in Two Dimensions. Therefore hypothesis 2 was supported and can be explained well.

Meanwhile, further investigation of research confirmed that third proposed hypothesis was supported and accepted which explains, there is a significant positive relationship between the perceived usefulness $(\beta=0.419)$ and students' attitude towards the use of GeoGebra In learning Loci in Two Dimensions. The positive attitude of students towards the use of GeoGebra is a result of reasons that the students found GeoGebra as a beneficial tool for them to learn Mathematics. This result corroborates the findings of (Saade, Nabebe, \& Tan, 2007).

Students who showed a positive attitude towards GeoGebra also showed positive behavior towards the software. This statement supported by hypothesis 4 which explains, there is significant and positive relationship between attitude $(\beta=0.965)$ and students' behavioral intention towards GeoGebra in Learning Loci in Two Dimensions. Measuring behavioral intention alone will not provide fruitful results because the behavioral intention is strongly dependent on attitude. At the same time, the attitude is dependent with two variables: perceived of use and perceived usefulness.

\section{Discussion}

There are few limitations in this study. This research was conducted with a sample of 30 form two students from a secondary school in Johor Bahru district. Since the sample does not represent the whole form two students in the school, therefore the findings cannot be concluded for all the form two students. Besides that, this research was conducted in only two days time, five hours per day which means total of ten hours lesson due to the disturbance of normal lesson in the particular school. The short time is not sufficient to study the interest level of students towards GeoGebra. This is mainly because in a longer period, we can determine whether the students' interest level getting increase or decrease towards the use of GeoGebra in learning Loci in Two Dimensions. On top of everything, lack of computers in the school caused the students had to share their computers with other students with maximum two persons per computer. However, both students were given opportunities to explore GeoGebra and to do the activities given.

Results of the present research led to the conclusion that the attitude of students towards the use of GeoGebra is determined by their perception on its usefulness and how convenient it is to use (Davis, 1993; Porter \& Donthu, 2006; Maslin, 2007; Norazah, 2011). The students tend to focus on the usefulness of GeoGebra before expressing their preference of the software. In other words, the students who are the future leaders are ready to integrate technology in their education if they find that the software is beneficial for them and it has the potential to enhance their knowledge and skill as well. Apart from that, the results show a remarkable consistency with the results of prior study (Salih, 2004) determining that computer enriched environment and multimedia-enhanced learning settings are positively correlated with students' attitudes towards computers in general and they can foster positive attitudes toward the use of computers in education. Additionally, according to Philip et al. (2011), computer assisted instruction (CAI) promotes encouraging attitudes towards Mathematics and teaching. 
GeoGebra has proven as an effective tool for the students to learn Loci in Two Dimensions. However, further studies should be embarking on to identify other factors that may assist to determine the attitude of students towards the use of GeoGebra in learning mathematics. At the same time, students should provide with ample time to familiarize with GeoGebra before the research being conducted. Further studies on using GeoGebra in various other topics such as Geometry, Calculus and Statistics are encouraged well. Future studies on GeoGebra should add the motivation element to test the motivational level in learning GeoGebra. Overall, GeoGebra is the best software to learn mathematics topic such as Loci in Two Dimension. It is very obvious that the students showed a positive attitude towards the use of GeoGebra in learning the particular topic. However, many researches should be conducted with the purpose of studying the attitude of students towards the software, so that the real context of majority students can be identified before the full implementation of GeoGebra in the school system.

\section{Acknowledgements}

The authors would like to thank the Ministry of Education (MOE), Malaysia and Universiti Teknologi Malaysia (UTM) for their financial funding through FRGS Grant Vote No. 4F187.

\section{References}

Alexiou-Ray, J., Wilson, E., Wright, V., Peirano, A. (2003). Changing Instructional Practice: The Impact of Technology Integration on Students, Parents and School Personnel. Electronic Journal for the Integration of Technology in Education.

Antohe. V. (2011). GeoGebra Software in Teaching- Learning Process. Annals. Computer Science Series $\left(9^{\text {th }}\right.$ Tome. Vol. 9. Fasc. 1).

Botana, F., \& Abánades, M. A. (2014). Automatic deduction in (dynamic) geometry: Loci computation. Computational Geometry, 47(1), 75-89. http://dx.doi.org/10.1016/j.comgeo.2013.07.001

Chan, S. W., \& Ismail, Z. (2014). A Technology-based Statistical Reasoning Assessment Tool in Descriptive Statistics for Secondary School Students. The Turkish Online Journal of Educational Technology, 13(1), 29-46.

Chan, S. W., \& Ismail, Z. (2012). The role of information technology in developing students' statistical reasoning. Procedia-Social and Behavioral Sciences, 46, 3660-3664. http://dx.doi.org/10.1016/j.sbspro.2012.06.123

David, H. J., Chad, C., \& Yueh, H.-P. (1998). Computers as Mindtools for Engaging Learners in Critical Thinking. TechTreds, 43(2), 23-32.

Davis, F. D. (1993). User Acceptance of Information Technology: System Characteristics, User Perceptions and Behavioral Impacts. International Journal of Man-Machine Studies, 38(3), 475-487. http://dx.doi.org/10.1006/imms.1993.1022

Dogan, M., \& Icel, R. (2010). The Role of Dynamic Geometry Software in The Process of Learning: GeoGebra Example about Triangles. Paper Presented at Third International Conference on Innovations in Learning for The Future 2010: E-Learning: First Eurasia Meeting Of GeoGebra (EMG). Istanbul, Turkey

Gorghiu, G., Pauna, N., \& Gorghiu, L. M. (2009). Solving Geometrical Locus Problems Using Dynamic Interactive Geometry Applications. Research, Reflections and Innovations in Integrating ICT in Education, 2, 681-1231.

Hohenwarter, M., \& Fuchs, K. (2004). Combination of dynamic geometry, algebra and calculus in the software system GeoGebra, 2002 (July).

Hohenwarter, M., \& Jones, K. (2007). Ways of Linking Geometry and Algebra: The Case of GeoGebra (November, pp. 126-131).

Hohenwarter, M., Hohenwarter, J., Kreis, Y., \& Lavicza, Z. (2008). Teaching and Calculus with Free Dynamic Mathematics Software GeoGebra. $11^{\text {th }}$ International Congress on Mathematical Education

Kamariah, A. B., Ahmad, F. M. A., \& Rohani, A. T. (2010). Utilization of Computer Technology in Learning Transformation. International Journal of Education and Information Technologies, 4(2).

Maslin, M. (2007). Technology Acceptance Model and E-Learning. $12^{\text {th }}$ International Conference on Education, Sultan Hassanal Bolkiah Institute of Education University Brunei Darussalam

Ministry of Education. (2002). Integrated Curriculum for Secondary Schools. Retrieved From http://kintautara.net/aee2071/index.php?option=com_remository\&Itemid=43\&fu nc=startdown\&id=35 
Muir-Herzig, R. G. (2004). Technology and Its Impact in the Classroom. Computers \& Education, 42(2), 111-131. http://dx.doi.org/10.1016/S0360-1315(03)00067-8

Norazah, M. S. (2011). Factors Affecting Third Generation (3G) Mobile Service Acceptance: Evidence from Malaysia. Journal of Internet Banking and Commerce, 16(1).

Philip, M. K., Jackson, T. K., \& Dave, W. (2011). The Effect of Computer-Assisted Instruction on Student's Attitudes and Achievement in Matrices and Transformations in Secondary Schools in Uasin Gishu District, Kenya. International Journal of Curriculum and Instruction, 1(1), 53-62.

Porter, C. E., \& Donthu, N. (2006). Using the Technology Acceptance Model to Explain How Attitudes Determine Internet Usage: The Role of Perceived Access Barriers and Demographics. Journal of Business Research, 59(9), 999-1007. http://dx.doi.org/10.1016/j.jbusres.2006.06.003

Reisa, Z. A. (2010). Computer supported mathematics with GeoGebra. Procedia-Social and Behavioral Sciences, 9, 1449-1455. http://dx.doi.org/10.1016/j.sbspro.2010.12.348

Saade, R. G., Nabebe, F., \& Tan, W. (2007). Viability of the 'Technology Acceptance Model' In Multimedia Learning Environments: A Comparative Study. Interdisciplinary Journal of Knowledge and Learning Objects, 3.

Salih, U. (2004). Undergraduate Students Attitudes on the Use of Computers in Education. The Turkish Online Journal of Educational Technology, 3(2).

Stojanovska, L. F., \& Stojanovski, V. (2010). GeoGebra in the College Classroom Multiple Representations. Proceedings of the First North American GeoGebra Conference, July 27-28, 2010 .Ithaca College, Ithaca, NY.

Volk, K. S., \& Yip, W. M. (1999). Gender and Technology in Hong Kong: A Study of Pupils' Attitudes towards Technology. International Journal of Technology and Design Education, 9(1), 57-71. http://dx.doi.org/10.1023/A:1008894006039

Zengin, Y., Furkan, H., \& Kutluca, T. (2012). The effect of dynamic mathematics software GeoGebra on student achievement in teaching of trigonometry. Procedia-Social and Behavioral Sciences, 31(2011), 183-187. http://dx.doi.org/10.1016/j.sbspro.2011.12.038

\section{Copyrights}

Copyright for this article is retained by the author(s), with first publication rights granted to the journal.

This is an open-access article distributed under the terms and conditions of the Creative Commons Attribution license (http://creativecommons.org/licenses/by/3.0/). 